\title{
From pseudohypoparathyroidism to
} inactivating PTH/PTHrP signalling disorder (iPPSD), a novel classification proposed by the EuroPHP network

\author{
Susanne Thiele', Giovanna Mantovani², Anne Barlier², Valentina Boldrin², Paolo Bordogna², \\ 'Division of Experimental Pediatric Endocrinology and Diabetes, Department of Pediatrics, University of \\ Lübeck, Lübeck, Germany, ${ }^{2}$ Fondazione IRCCS Ca' Granda Ospedale Maggiore Policlinico, Endocrinology \\ and Diabetology Unit, Department of Clinical Sciences and Community Health, University of Milan, \\ Milan, Italy, ${ }^{3} \mathrm{APHM}$, Hôpital la Conception, Laboratory of Molecular Biology, Marseille, France, \\ ${ }^{4}$ Department of Public Health and Pediatric Sciences, University of Torino, Torino, Italy, ${ }^{5}$ Department of \\ Cardiovascular Sciences, Center for Molecular and Vascular Biology, University of Leuven, Leuven, \\ Belgium, ${ }^{6}$ Molecular (Epi)Genetics Laboratory, BioAraba National Health Institute, OSI Araba University \\ Hospital, Vitoria-Gasteiz, Spain, ${ }^{7}$ APHP, Reference Center for rare disorders of the Calcium and \\ Phosphate Metabolism, filière OSCAR and Plateforme d'Expertise Maladies Rares Paris-Sud, Hôpital \\ Bicêtre Paris Sud, Le Kremlin Bicêtre, France, ${ }^{8}$ INSERM U1169, Hôpital Bicêtre, Le Kremlin Bicêtre, et \\ Université Paris-Saclay, Le Kremlin Bicêtre, France, ${ }^{9}$ Department of Endocrinology and Nutrition, La Paz \\ University Hospital, Madrid, Spain, ${ }^{10}$ Department of Biochemistry and Molecular Biology, University of \\ Basque Country, Leioa, Spain, "1Department of Endocrinology and Diabetes, Birmingham Children's \\ Hospital, Birmingham, UK, ${ }^{12}$ APHP, Service de Biochimie et Génétique Moléculaires, Hôpital Cochin, \\ Paris, France, ${ }^{13}$ Department of Pediatrics, Division of Endocrinology and Diabetes, Marmara University, \\ Istanbul, Turkey, ${ }^{14} \mathrm{APHP}$, Department of Paediatric Endocrinology and Diabetology, Bicêtre Paris Sud \\ hospital, Le Kremlin Bicêtre, France
} Luisa De Sanctis ${ }^{4}$, Francesca M Elli², Kathleen Freson ${ }^{5}$, Intza Garin ${ }^{6}$, Virginie Grybek ${ }^{7,8}$, Patrick Hanna7,8, Benedetta Izzi ${ }^{5}$, Olaf Hiort ${ }^{1}$, Beatriz Lecumberri' ${ }^{9}$ Arrate Pereda ${ }^{6,10}$, Vrinda Saraff ${ }^{11}$, Caroline Silve $^{7,8,12}$, Serap Turan ${ }^{13}$, Alessia Usardi7,14, Ralf Werner1, Guiomar Perez de Nanclares ${ }^{6}$ and Agnès Linglart ${ }^{7,8,14}$
Correspondence should be addressed to A Linglart Email agnes.linglart@aphp.fr

\begin{abstract}
Objective: Disorders caused by impairments in the parathyroid hormone (PTH) signalling pathway are historically classified under the term pseudohypoparathyroidism (PHP), which encompasses rare, related and highly heterogeneous diseases with demonstrated (epi)genetic causes. The actual classification is based on the presence or absence of specific clinical and biochemical signs together with an in vivo response to exogenous PTH and the results of an in vitro assay to measure Gsa protein activity. However, this classification disregards other related diseases such as acrodysostosis (ACRDYS) or progressive osseous heteroplasia (POH), as well as recent findings of clinical and genetic/epigenetic background of the different subtypes. Therefore, the EuroPHP network decided to develop a new classification that encompasses all disorders with impairments in PTH and/or PTHrP CAMP-mediated pathway. Design and methods: Extensive review of the literature was performed. Several meetings were organised to discuss about a new, more effective and accurate way to describe disorders caused by abnormalities of the PTH/PTHrP signalling pathway. Results and conclusions: After determining the major and minor criteria to be considered for the diagnosis of these disorders, we proposed to group them under the term 'inactivating PTH/PTHrP signalling disorder' (iPPSD). This terminology: (i) defines the common mechanism responsible for all diseases; (ii) does not require a confirmed genetic defect; (iii) avoids ambiguous terms like 'pseudo' and (iv) eliminates the clinical or molecular overlap
\end{abstract}

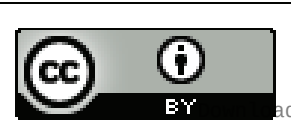

This work is licensed under a Creative Commons Attribution 3.0 Unported License 
between diseases. We believe that the use of this nomenclature and classification will facilitate the development of rationale and comprehensive international guidelines for the diagnosis and treatment of iPPSDs.

\section{Introduction}

Pseudohypoparathyroidism (PHP) encompasses a group of rare, related, highly heterogeneous and deeply impairing disorders characterised by end-organ resistance to the action of parathyroid hormone (PTH) and in most instances associated with a demonstrated (epi)genetic component $(1,2,3)$. PHP is historically the first hormoneresistance syndrome described by Albright et al. (4).

A better understanding of the PHP pathophysiology followed the identification of the PTH receptor (PTH1R) and its signal transduction pathway (Fig. 1) $(5,6)$. PTH1R, through its activation by two ligands, the PTH and the PTH-related peptide (PTHrP), regulates skeletal development, bone turnover and mineral ion homeostasis. In the kidney, binding of PTH to PTH1R stimulates the production of 1,25-dihydroxy vitamin D3, and inhibits phosphate reabsorption in the proximal tubule, while it increases calcium reabsorption in the distal nephron. In the growth plate,

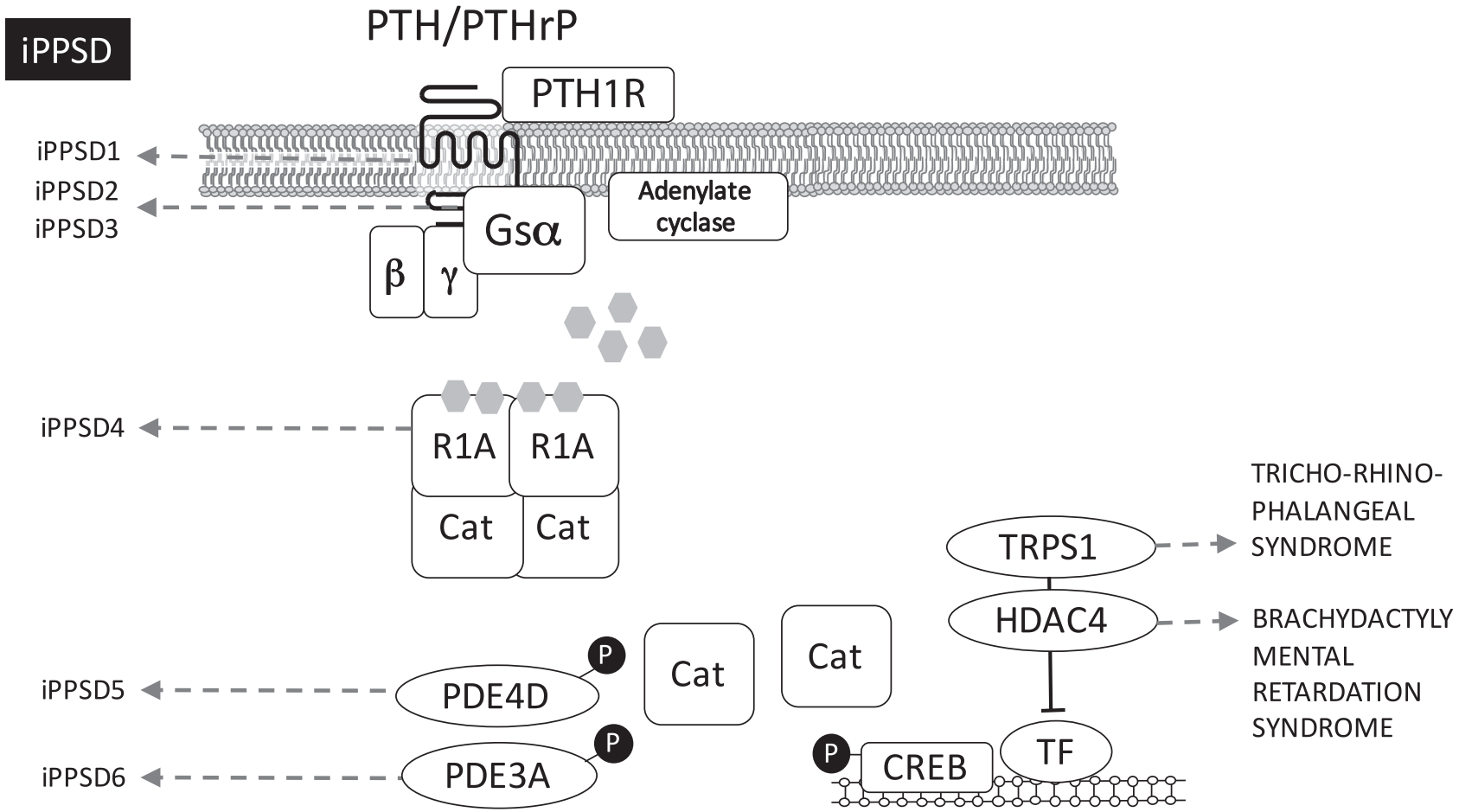

\section{Figure 1}

Schematic transduction of PTH1R/Gsa/CAMP/PKA pathway. Upon ligand binding (PTH or PTHrP is mentioned in the figure), the receptor (PTH1R) activates the G protein. Then, the Gsa subunit triggers the activation of the adenylate cyclase leading to CAMP synthesis. CAMP binds to the regulatory 1A subunits (R1A) of the PKA, the most common effector of cAMP. Upon CAMP (grey diamonds) binding, the catalytic subunits (Cat) dissociate from the R1A subunits, and phosphorylate numerous target proteins including CREB (CAMP-responsive binding elements) and the phosphodiesterases (PDEs). CREB activates the transcription of CAMP-responsive genes. Intracellular CAMP is then deactivated by PDEs, among which are PDE4D and PDE3A. PTH1R: transmembrane convolutional black line; G protein: trimer $\alpha, \beta, \gamma$; cAMP: grey diamond; PKA: tetramer R1A (regulatory subunit $1 \mathrm{~A}$ ) and Cat (catalytic subunit); phosphodiesterases: ovals PDE4D or PDE3A; DNA: scale bar. 
PTHrP promotes endochondral ossification, by binding to PTH1R (7).

The Blomstrand chondrodysplasia (OMIM \#215045), a lethal form of dwarfism (8), was the first disorder associated with biallelic loss-of-function mutations of the PTH1R gene (9). Subsequently, one report has described a milder phenotype in living children affected with Eiken disease (OMIM \#600002), short stature, elevated PTH and mutations of PTH1R $(10,11)$.

A defect in the response of the proximal renal tubule to PTH is the hallmark of all forms of PHP. It manifests as hypocalcaemia, hyperphosphataemia and elevated circulating levels of PTH in the absence of vitamin D deficiency $(5,7,12)$.

PTH receptor couples with the stimulatory G protein (Gsa), leading to cAMP formation. Renal tubular response to exogenously administered PTH through measurement of serum and urinary cAMP levels permits the differentiation of PHP type 1 (PHP1), in which a blunted cAMP response is observed, from PHP type 2 (PHP2), where cAMP increase is conserved but the phosphaturic response is deficient (13). To date, only a handful of PHP2 cases have been reported, and the molecular defect responsible for this variant is still unknown. It has also been hypothesised that PHP2 could either be an acquired defect secondary to vitamin D deficiency (14), as calcium and vitamin $\mathrm{D}$ supplementation resulted in normalisation of the phosphaturic response to PTH in some patients $(14,15)$, or due to defects downstream the Gsa protein, as seen in patients with acrodysostosis type 1 (ACRDYS1) (16).

In 1980, deficiency in the Gsa protein activity in erythrocytes extracted from patients affected with PHP1 was demonstrated in vitro $(17,18)$. For years, this bioassay allowed the diagnosis of PHP, and contributed to PHP subclassification (see below).

PHP type 1 (PHP1) is further subdivided based on the presence (PHP1A and PHP1C; OMIM \#103580 and \#612462 respectively) $(6,17,18,19)$ or absence (PHP1B; OMIM \#603233) $(6,20)$ of Albright hereditary osteodystrophy (AHO) (Table 1). AHO is a clinical entity initially described together with PHP in 1942, which encompasses heterogeneous clinical findings such as brachydactyly, rounded face, short stature, stocky build and subcutaneous ossifications $(4,21,22)$. Additional features that may not directly relate to $\mathrm{AHO}$, yet extensively associated with PHP1A individuals, include obesity, varying degrees of intellectual disability and resistance to several hormones, including TSH, GHRH and calcitonin $(23,24,25,26,27,28)$. The subcategory of PHP1C has all the characteristics of PHP1A, except that
Gsa activity in erythrocytes was found comparable to controls $(29,30)$.

Interestingly, patients showing the physical features of AHO without any evidence of PTH resistance were also described by Albright et al. (21) 10 years after their first report of PHP. This new syndrome, named pseudopseudohypoparathyroidism (PPHP; OMIM \#612463) may be present either in kindreds with PHP or as an isolated defect. It is possible that the 'bone phenotype' observed in AHO is largely mediated by the resistance to PTHrP at the growth plate during foetal and postnatal growth (31).

In 1990, the first heterozygous inactivating mutation in the gene coding for Gsa (GNAS), responsible for PHP1A, was described (32). Since then, several Gsa-coding mutations have been identified in all of its 13 exons with different frequency, with a detection rate of about $70 \%$ $(33,34,35,36,37,38,39)$. Cases of deletions of 20q, including part or the whole GNAS gene, and an inversion at GNAS have been recently reported (40, 41, 42, 43, 44). Remarkably, similar mutations when paternally inherited, or occurring de novo on the paternal allele of GNAS may lead to PPHP or to progressive osseous heteroplasia ( $\mathrm{POH}$, OMIM \#166350), a disorder characterised by heterotopic ossifications expanding into deep muscles and connective tissues $(45,46)$.

GNAS is a locus encoding several transcripts through alternative splicing. In most tissues, except for Gsa, the GNAS transcripts are of monoallelic origin due to the control of their expression by parent-specific differentially methylated regions (DMRs) (Fig. 2) (47). In thyroid, pituitary gland and most likely in the proximal tubule (36), Gsa is predominantly expressed from the maternal allele through a yet unexplained mechanism $(48,49)$. In the early 2000 , the molecular defect of PHP1B was characterised. The most consistent defect common to all PHP1B patients is a paternal-specific pattern of cytosine methylation within the maternal GNAS A/B: transcriptional start site (TSS)-DMR (GNAS $A / B$ :TSS-DMR; previously known as exon $\mathrm{A} / \mathrm{B}$ or $1 \mathrm{~A}$ ), which could lead to a decreased expression of Gsa in the renal proximal tubules, hence PTH resistance (50). Fifteen to twenty percent of the PHP1B cases present familial history with an autosomal dominant mode of inheritance (AD-PHP1B) through the maternal lineage. Most AD-PHP1B show loss of imprinting (LOI) limited to the GNAS A/B:TSS-DMR (more precisely a loss of methylation (LOM)) associated with deletions on the maternal allele of cis-acting control elements within STX16 or NESP55 (51,52, 53,54,55), although other 
Table 1 Former classification of PHP along with the other disorders affecting the PTH/PTHrP signalling pathway; note the overlap of phenotypes and molecular defects of the patients. Diseases included in the former classification are PHP1A, PHP1B, PHP1C and PPHP.

\begin{tabular}{|c|c|c|c|c|c|c|c|c|}
\hline & PHP1A & PHP1C & & & PHP1 & & & \\
\hline \multirow[t]{3}{*}{$\begin{array}{l}\text { Clinical } \\
\text { presentation }\end{array}$} & $\mathrm{AHO}$ & $\mathrm{AHO}$ & No AHO & $\begin{array}{l}\text { AHO in some } \\
\text { patients } \\
\text { (brachydactyly, } \\
\text { subcutaneous } \\
\text { ossification) } \\
\text { and/or obesity }\end{array}$ & $\begin{array}{l}\text { AHO in very } \\
\text { few } \\
\text { patients }\end{array}$ & $\begin{array}{l}\text { Mental } \\
\text { retardation } \\
\text { reported in } \\
2 \text { patients, } \\
\text { lambdoid } \\
\text { synostosis, } \\
\text { early-onset } \\
\text { obesity, } \\
\text { macrocephaly }\end{array}$ & BWS & No AHO \\
\hline & Obesity & Obesity & No obesity & & $\begin{array}{l}\text { Obesity } \\
\text { may be } \\
\text { present }\end{array}$ & & Obesity & No obesity \\
\hline & $\begin{array}{l}\text { Cognitive } \\
\text { impairment } \\
\text { Subcutaneous } \\
\text { ossifications }\end{array}$ & $\begin{array}{l}\text { Cognitive } \\
\text { impairment } \\
\text { Subcutaneous } \\
\text { ossifications }\end{array}$ & $\begin{array}{c}\text { No cognitive } \\
\text { impairment }\end{array}$ & & & & & \\
\hline $\begin{array}{l}\text { Hormone } \\
\text { resistance }\end{array}$ & $\begin{array}{l}\text { Resistance to } \\
\text { PTH, TSH, } \\
\text { GHRH, } \\
\text { calcitonin, } \\
\text { epinephrine, } \\
\text { glucagon and } \\
\text { gonadotropins }\end{array}$ & $\begin{array}{l}\text { Resistance to } \\
\text { PTH, TSH, } \\
\text { epinephrine } \\
\text { and } \\
\text { gonadotropins }\end{array}$ & PTH resistance & $\begin{array}{l}\text { PTH resistance, } \\
\pm \mathrm{TSH} \\
\text { resistance }\end{array}$ & $\begin{array}{l}\text { PTH } \\
\text { resistance, } \\
\pm \mathrm{TSH} \\
\text { resistance }\end{array}$ & $\begin{array}{l}\text { PTH resistance, } \\
\pm \mathrm{TSH} \\
\text { resistance }\end{array}$ & $\begin{array}{l}\text { PTH } \\
\text { resistance }\end{array}$ & $\begin{array}{l}\text { PTH } \\
\text { resistance, } \\
\pm \text { TSH } \\
\text { resistance }\end{array}$ \\
\hline $\begin{array}{l}\text { In vitro } \\
\text { activity of } \\
\text { Gsa }\end{array}$ & $\begin{array}{l}\text { Significantly } \\
\text { below controls }\end{array}$ & $\begin{array}{c}\text { Similar to } \\
\text { controls }\end{array}$ & $\begin{array}{l}\text { Similar to } \\
\text { controls }\end{array}$ & $\begin{array}{l}\text { Mildly } \\
\text { decreased } \\
\text { when } \\
\text { compared with } \\
\text { controls }\end{array}$ & $\begin{array}{l}\text { Mildly } \\
\text { decreased } \\
\text { when } \\
\text { compared } \\
\text { with } \\
\text { controls }\end{array}$ & & & $\begin{array}{c}\text { Similar to } \\
\text { controls }\end{array}$ \\
\hline $\begin{array}{l}\text { LOI at the } \\
\text { GNAS DMRs }\end{array}$ & & & & $\begin{array}{l}\text { LOM at the } \\
\text { GNAS } \\
\text { A/B:TSS-DMR }\end{array}$ & Broad LOI & Broad LOI & Broad LOI & Broad LOI \\
\hline Genetic lesion & $\begin{array}{l}\text { Heterozygous } \\
\text { mutation in } \\
\text { the coding } \\
\text { sequence of } \\
\text { GNAS } \\
\text { (maternal } \\
\text { allele) }\end{array}$ & $\begin{array}{l}\text { Heterozygous } \\
\text { mutation in } \\
\text { the coding } \\
\text { sequence of } \\
\text { GNAS } \\
\text { (p.E392K, } \\
\text { p.E392X, } \\
\text { p.L388R and } \\
\text { p.Y391X, all in } \\
\text { exon 13) } \\
\text { (maternal } \\
\text { allele) }\end{array}$ & $\begin{array}{l}\text { Heterozygous } \\
\text { mutation in } \\
\text { the coding } \\
\text { sequence of } \\
\text { GNAS } \\
\text { (p.lle382del) } \\
\text { (maternal } \\
\text { allele) }\end{array}$ & $\begin{array}{l}\text { Recurrent 3-kb } \\
\text { STX16 deletion } \\
\text { or } 4.2-\mathrm{kb} \\
\text { deletion of } \\
\text { STX16 }\end{array}$ & Unknown & $\begin{array}{l}\text { UPD(20)pat } \\
\text { including } \\
\text { GNAS }\end{array}$ & MLID & $\begin{array}{l}\text { Maternal } \\
\text { deletion of } \\
\text { NESP and/ } \\
\text { or AS or } \\
\text { duplication } \\
\text { of GNAS }\end{array}$ \\
\hline References & $\begin{array}{r}(32,33,34,35 \\
36,37,38,39)\end{array}$ & $(29,30,78)$ & $(112)$ & $(50,51,52,113)$ & $\begin{array}{l}(50,51,63, \\
74)\end{array}$ & $\begin{array}{l}(59,60,61,62, \\
63)\end{array}$ & $(114)$ & $\begin{array}{l}(53,54,58, \\
115)\end{array}$ \\
\hline
\end{tabular}




\begin{tabular}{cc}
\hline & \\
& PPHP \\
\hline AHO & AHO
\end{tabular}

\begin{tabular}{lll}
\hline & $\begin{array}{l}\text { 2q37.3 } \\
\text { Deletion } \\
\text { Syndrome }\end{array}$ \\
\cline { 1 - 1 } POH & AHO
\end{tabular}

Subcutaneous $\mathrm{AHO}$ ossifications

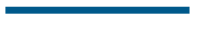

PHP2

No AHO Severe AHO AHO Severe AHO

Blomstrand Eiken dysplasia

Lethal dwarfism disease

Epiphyseal dysplasia
Subcutaneous Subcutaneous ossifications ossifications

\section{No}

Mild

No
Cognitive

impairment

Hypocalcaemia,
osteomalacia

impairment

in some

patients

No
Cognitive
PTH resistance PTH

resistance, and $\mathrm{TSH}$ in

some

patients
PTH

resistance, and TSH in

some

patients
Hypertension

No

thertension

西

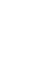

Short stature

Elevated

PTH in one patient

\section{Significantly Significantly \\ below below \\ controls controls}

Heterozygous Heterozygous Heterozygous Deletion of None mutation in

the coding

sequence of

GNAS

(paternal

allele)

mutation in
the coding
sequence of
GNAS
(paternal
allele)

mutation in the $2 \mathrm{q} 37$.

the coding chromosomal

sequence of

GNAS

region

(paternal

including

allele) or no

mutation

identified
Heterozygous H mutation in

the coding

sequence of

PRKAR1A or

PDE4D
Heterozygous mutation in the coding sequence of PRKAR1A

\section{mutation in} the coding sequence of PDE3A
Biallelic

inactivating mutation in the coding sequence of

PTH1R
Biallelic inactivating mutation in the coding sequence of PTH1R
(34, 36, 44,
(77)
$(39,45,46$,

(116)

(14)
$(16,82,90$,
$(90,91)$
$91,117,118$
119)

(92)

$(9,11)$

(10)

AHO, Albright's hereditary osteodystrophy; BWS, Beckwith-Wiedemann syndrome; MLID, multilocus imprinting defect; NA, not available; PHP, pseudohypoparathyroidism; PPHP, pseudopseudohypoparathyroidism. 


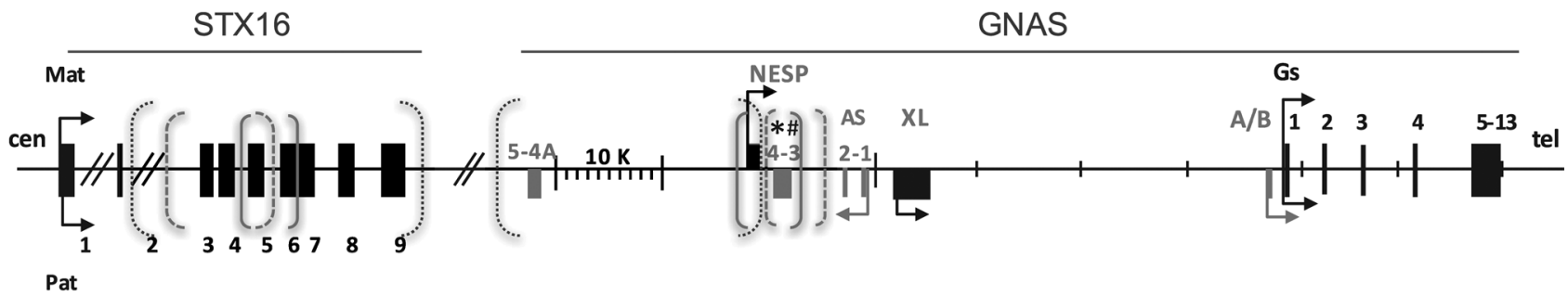

\section{Figure 2}

The imprinted human GNAS locus (Hg19-chr20:57,414,795-57,486,250), on chromosome 20, close to the STX16 gene (Hg19chr20:57,226,309-57,254,5812) (source UCSC, Hg19). The centromeric/telomeric orientation of the chromosome is indicated. The maternal (NESP), paternal ( $\mathrm{BB}, \mathrm{AS}$ and $\mathrm{XL}$ ) and biallelic (Gsa) transcripts are depicted as arrows. Maternal- and paternal-expressed transcripts are drawn above and below the horizontal line respectively. Black boxes: coding exons; grey boxes: noncoding exons; arrows: transcription (direction and parental origin). The brackets delimit the imprinting control element deletions, which have been reported. STX16 gene: full brackets: the recurrent STX16 deletion of 3.3 kb (38); large dotted brackets: the STX16 deletion of $4.4 \mathrm{~kb}$ (39); small dotted brackets: the STX16 deletion of $29.5 \mathrm{~kb}$ (42). GNAS locus: full brackets: the 4.7 and $4 \mathrm{~kb}$ deletions removing the NESP exon and exons 3 and 4 of GNAS-AS1 (40); large dotted brackets: the $4.2 \mathrm{~kb}$ deletion removing exons 3 and 4 of GNAS-AS1 (43); deletions of $40 \mathrm{pb}\left({ }^{*}\right)$ and $33 \mathrm{pb}(\#)$ in introns of NESP and GNAS-AS1 (44); small dotted brackets: the NESP and GNAS-AS1 deletion (41). cen, centromeric; Mat, maternal; Pat, paternal; tel, telomeric.

maternally inherited deletions have been identified affecting all four DMRs (GNAS-NESP:TSS-DMR, GNASAS1:TSS-DMR, GNAS-XL:Ex1-DMR and GNAS A/B:TSSDMR) $(56,57,58)$.

The remaining cases of PHP1B are sporadic. They present with broad LOI at GNAS, including the GNAS $A / B$ :TSS-DMR. The molecular basis of this broad LOI is yet to be identified, with an exception of less than $10 \%$ of the patients who are affected by paternal complete or segmental uniparental disomy (UPD) of the chromosome 20, comprising the GNAS locus (59, 60, 61, 62, 63).

To summarise, the existing classification of PHP (Table 1) is based on the following criteria: (i) presence or absence of AHO differentiates PHP1A/PHP1C from PHP1B; (ii) presence or absence of hormonal resistance differentiates PHP1 from PPHP; (iii) in vivo response to exogenous PTH as for nephrogenic cAMP synthesis and phosphaturia separates PHP1 from PHP2 and (iv) in vitro assay measuring the Gsa protein activity from erythrocyte membranes differentiates between PHP1A and PHP1C.

As described above, the existing PHP classification does not include molecular defect as a criterion and fails to stratify $\mathrm{PHP}$ and $\mathrm{AHO}$ as well as include conditions such as acrodysostosis, POH and PTH1R-related chondrodysplasia. In this manuscript, we therefore propose to review the rationale of this nomenclature and recommend a novel classification for disorders impairing the PTH/PTHrP signalling pathway.

\section{Methodology}

The EuroPHP network met on three different occasions (October 2014, May 2015, November 2015) to discuss and agree on a novel classification. The aims of these meetings were (i) to identify the limitations in the current PHP classification; (ii) to formulate mandatory criteria for the new classification; (iii) to propose a comprehensive definition gathering all the disorders; (iv) to analyse the classifications used in other genetic/epigenetic conditions and (v) to generate a novel classification. The methodology comprised a thorough review of the current literature to facilitate comparison and form basis for the proposal of a new classification.

We have carefully considered a series of classifications proposed for various rare genetic/epigenetic disorders, including the reporting manuscripts that were taken into consideration for the design of a novel classification (summarised in Table 2). In brief, methodologies were similar. A group of experts in the field identified the deficiencies in the existing classification/terminology and the need for an update. Subsequently, agreement on a novel terminology and classification was reached and reported $(64,65,66,67,68,69,70)$.

\section{Challenges and limitations of the current classification}

Recent clinical and molecular data gathered for these complex disorders have questioned the distinction 
Table 2 Nonexhaustive review of classifications used in other conditions.

\begin{tabular}{|c|c|c|}
\hline & $\begin{array}{l}\text { Methodology used to } \\
\text { build the classification }\end{array}$ & Mode of classification \\
\hline $\begin{array}{l}\text { Primary } \\
\text { immunodeficiency } \\
\text { diseases (69) }\end{array}$ & 2-days meeting & $\begin{array}{l}\text { Groups of diseases } \\
\text { according to the most } \\
\text { fundamental defect } \\
\text { presented as a table } \\
\text { format }\end{array}$ \\
\hline Skeletal dysplasia (66) & $\begin{array}{l}\text { Meeting, extensive } \\
\text { review of the } \\
\text { literature, and } \\
\text { circulation of drafts of } \\
\text { the manuscript }\end{array}$ & $\begin{array}{l}\text { Groups of diseases } \\
\text { defined by molecular, } \\
\text { biochemical and/or } \\
\text { radiographic criteria }\end{array}$ \\
\hline \multirow{2}{*}{$\begin{array}{l}\text { Autosomal dominant } \\
\text { tubule interstitial } \\
\text { kidney disease (67) }\end{array}$} & $\begin{array}{l}\text { Meeting, agreement on } \\
\text { the manuscript }\end{array}$ & $\begin{array}{l}\text { Agreement on a novel } \\
\text { name: ADTKD }\end{array}$ \\
\hline & & $\begin{array}{l}\text { Classification based on } \\
\text { the underlying genetic } \\
\text { defect: ADTKD-gene }\end{array}$ \\
\hline Endocrine diseases (68) & Literature review & $\begin{array}{l}\text { Groups of diseases by } \\
\text { organ }\end{array}$ \\
\hline $\begin{array}{l}\text { Diabetes mellitus } \\
\text { (MODY) (70) }\end{array}$ & $\begin{array}{l}\text { Meetings, agreement on } \\
\text { the manuscript }\end{array}$ & $\begin{array}{l}\text { Groups of diabetes by } \\
\text { diseases' mechanism }\end{array}$ \\
\hline $\begin{array}{l}\text { Osteogenesis imperfecta } \\
\text { (64) }\end{array}$ & Literature review & $\begin{array}{l}\text { Phenotypes on } \\
\text { evolution, radiology, } \\
\text { clinics and genetics }\end{array}$ \\
\hline
\end{tabular}

\begin{tabular}{l} 
Advantages \\
\hline Allows a practical \\
clinical framework for \\
PID diagnosis \\
\\
Disorders are caused by \\
disturbances in related \\
metabolic pathways or \\
gene networks, Sheer \\
number of conditions \\
included \\
Provide information on \\
the disease
\end{tabular}
the disease

Provide information on the disease mechanism

Allow numbering of new diabetes after identification of new genes for MODY (MODY1, MODY2, MODY3, MODY4...) Provide information on the disease mechanism and genetics
Limitations

The complexities of these conditions cannot easily be captured in the limited table format

The 'hybrid' nature of the classification, not clinical, not molecular

Use in communication with patients may not be easy

Very large groups of disease (type 2 diabetes for example)

Confusing as one causing gene may be in different categories of the different PHP and AHO subtypes in the existing classification (Table 1). We have selected the following limits of the current classification:

1. In a subset of patients with PHP1A and varying degree of AHO, LOI of GNAS identical to that of PHP1B has been reported, suggesting a molecular and clinical overlap between the two subtypes (71), further confirmed $(72,73,74,75)$.

2. PHP1B patients present with a moderate reduction in Gsa activity in erythrocyte membranes, reminiscent yet less severe - to that observed in patients with PHP1A and PPHP (76).

3. Recently, mild resistance to PTH was described in patients affected with PPHP, carrying a paternal GNAS mutation (77), showing that the hormonal resistance is not only associated with maternally inherited GNAS mutations.

4. Different molecular defects have been identified in patients with PHP1C, i.e. LOI at GNAS and four lossof-function mutations in the GNAS carboxyl-terminus leading to a conserved adenylyl cyclase receptorindependent activation but disrupted receptormediated activation $(29,30,78)$.
5. Paternal GNAS mutations associated with progressive osseous heteroplasia are usually truncating mutations (79), yet they are identical to those found in families with PHP1A and/or PPHP (45). Also noteworthy is that a fraction of $\mathrm{POH}$ patients exhibits some of the typical AHO features and, conversely, some PHP1A patients carrying mutations on the maternal allele present with progressive deepening heterotopic ossifications. The hypothesis that $\mathrm{POH}$ should be considered as a form of PPHP is, therefore, debated $(80,81)$.

6. Heterozygous mutations in PRKAR1A - coding for the regulatory subunit of the protein kinase A (PKA) - and PDE $4 D$ - coding for phosphodiesterase type 4 - have been found in patients with acrodysostosis $(16,82$, 83). Acrodysostosis refers to a heterogeneous group of rare diseases characterised by skeletal dysplasia and characteristic features, including brachydactyly, facial dysmorphism and, in some cases, mental retardation $(84,85,86,87,88)$. Acrodysostosis differs from PHP by more generalised osseous abnormalities $(87,89)$. Resistance to PTH and/or TSH is present in about $60-70 \%$ of acrodysostosis patients with a PRKAR1A mutation, while, in case of a PDE $4 D$ mutation, such hormone resistances are found only in a smaller 
subset of $10-20 \%$. Interestingly, few patients bearing a PRKAR1A mutation have been described in patients with a phenotype indistinguishable from PHP1A $(90,91)$.

7. Heterozygous mutations in PDE3A have been identified in patients affected with hypertension and brachydactyly type E (hypertension and brachydactyly syndrome (HTNB): OMIM \#112410) (92).

8. Disorders associated with an impaired function of PTH1R, i.e. the Blomstrand and Eiken skeletal dysplasia, are currently not included in the classification.

Over the past two decades, it became obvious that clinical features such as AHO or in vitro assays such as Gsa bioactivity fail to differentiate between PHP subtypes. In addition, mutations of genes different from GNAS have been shown to lead to PTH and/or PTHrP resistance and GNAS mutations might trigger diseases different from PHP/PPHP (i.e. POH). These disorders are not encompassed by the current classification system.

For all these reasons, different independent studies from the authors of the present paper, as well as the 'EuroPHP network' concluded and agreed that a uniform terminology is required to create a functional working classification that reflects the current knowledge of the diseases $(29,93,94)$.

\section{Terminology}

We propose the term of 'inactivating PTH/PTHrP signalling disorder', abbreviated as iPPSD, which encompass all disorders related to this pathway. We also propose that numbering will allow for both clinical features and molecular and genetic findings to be included. The advantages of this terminology are as follows: (i) it describes the common mechanism responsible for the diseases; (ii) it does not require a confirmed genetic defect; (iii) it avoids the ambiguous term like 'pseudo'; (iv) it eliminates the clinical or molecular overlap between diseases and (v) it is flexible to incorporate new evolving information.

We recognise that the nomenclature inactivating PTH/PTHrP signalling disorder' might be initially difficult for patients and caregivers to remember. It would, therefore, be helpful to rely on the abbreviation iPPSD. Equally, the former terms 'pseudohypoparathyroidism' and 'pseudopseudohypoparathyroidism' were also long and challenging to use for communication. PTH/PTHrPspecific pathway was deliberately included in the name of the classification to avoid the misperception with disorders resulting from the inactivation of $G$ proteincoupled receptors, i.e. inactivating mutations in the TSH receptor or in the FSH receptor. All nomenclature based on the cAMP signalling were carefully considered and rejected due to their generic nature.

\section{Identification of mandatory criteria for the new classification}

Basis for the newly proposed classification of iPPSD are:

- $\quad$ to provide patients with an unambiguous diagnosis;

- to base nomenclature on pathophysiology, i.e. the PTH1R/Gsa/cAMP/PKA pathway, and a standardised diagnostic pathway;

- to formulate basis to develop new therapeutic approaches;

- to be sufficiently flexible and adaptable to include emerging clinical and molecular information;

- to be simple and usable for the caregivers.

It is, therefore, of significant importance to define the category of iPPSD a patient belongs to, based on the characterisation of clinical/biochemical criteria, to facilitate a definitive diagnosis and, if possible, through molecular analysis, a more specific denomination within the classification.

We suggest three key clinical features as major criteria for the diagnosis of iPPSD. The proposed major criteria have minimum or no overlap with other conditions due to different mechanisms (Table 3, especially for the differential diagnoses).

We also propose a list of minor criteria that are associated with iPPSD. These are less specific to iPPSD compared with major criteria and can occur in other clinical conditions. Therefore, minor criteria need to be combined with one or more major criteria to establish the diagnosis of iPPSD.

\section{Major criteria}

\section{PTH resistance}

The hallmark of inactivating PTH/PTHrP signalling disorders is the resistance of the renal proximal tubule to the action of PTH. All genetic defects leading to a deficient PTH1R signalling in the kidney will, therefore, be named iPPSD.

\section{Ectopic ossifications}

Ectopic ossifications are superficial, subcutaneous nodules, defined as ectopic bone formation in the adipose or dermal tissue. Progressive osseous heterotopic calcifications often begin in the dermal and subcutaneous tissues and later 
Table 3 Definition of major and minor criteria for iPPSD and differential diagnoses.

\begin{tabular}{|c|c|c|}
\hline & & Assessment \\
\hline \multirow[t]{11}{*}{ I. Major criteria } & 1. PTH resistance & Ionized calcium, total calcium \\
\hline & & Phosphate \\
\hline & & Magnesium \\
\hline & & PTH \\
\hline & & Vitamin D (25OHD) \\
\hline & & Creatinine \\
\hline & & Urinary calcium \\
\hline & & Urinary phosphate \\
\hline & & $\begin{array}{l}\text { PTH infusion test in challenging } \\
\text { cases }\end{array}$ \\
\hline & 2. Ectopic ossification & Detailed physical exam \\
\hline & & X-rays \\
\hline
\end{tabular}

3. Brachydactyly type E Clinical inspection (fist), hand and (comprises the IV) feet X-rays

\section{Differential diagnosis \\ Normocalcaemic hyperparathyroidism Renal failure Vitamin D deficiency or any kind of secondary hyperparathyroidism}

\section{Fibrodysplasia ossificans progressiva (FOP, OMIM \#135100), post-traumatic osteoma cutis \\ Turner syndrome, tricho-rhino-phalangeal syndrome (TRPS), TRPS I, (OMIM \#190350), TRPS-II (OMIM \#150230) and TRPS-III, (OMIM \#190351) \\ Mutations in the TSH receptor}

$(26,27)$

IGF-1 (GH stimulation test if

$(2,27,78,98$, $99,100,101)$ necessary), calcitonin, LH, FSH, $\mathrm{GnRH}$ test

3. Motor and cognitive Computed tomography scan and/or retardation or MRI of the brain, psychopathoimpairment

4. Intrauterine and postnatal growth retardation

logical rating scales adjusted

for age

IUGR: gestational age, birth weight, birth length, head circumference, comparison to reference charts; post-natal growth: growth charts, $X$-ray of the left hand for determination of the bone age

5. Obesity/overweight Weight SDS, BMI percentile, BMI z-score

6. Flat nasal bridge Clinical inspection and/or maxillar hypoplasia and/or round face

iPPSD clinical diagnosis (a) Presence of one major criteria, either number 1 or 2;

(b) Presence of major criteria number 3 and at least 2 minor criteria ${ }^{\ddagger}$ $(23,105,106)$

$(24,25,34,85$

$86,102,116)$

$(16,40,92,103$, $104,120)$

$(4,84,86,90)$

†US in adults with hypothyroidism and no evidence for autoimmunity; thyroid imaging through thyroid scintigraphy and US in neonates diagnosed through screening for congenital hypothyroidism; ${ }^{*}$ Minor criteria are nonspecific (obesity/cognitive impairment); for instance, the association of $\mathrm{BDE}+$ obesity or $\mathrm{BDE}+$ cognitive impairment would not be relevant for our classification. By raising the number of minor criteria from 1 to 2 , we will reduce the risk of overdiagnosing patients with iPPSD.

progress to the deeper tissues, such as muscles and tendons. In children, ectopic ossifications are highly suggestive of an inactivating GNAS mutation, i.e. iPPSD.

\section{Brachydactyly}

Brachydactyly refers to shortening of fingers, toes or both. Brachydactyly type E (BDE, OMIM \#113300) encompasses variable shortening of the metacarpals/metatarsals, often with the involvement of phalanges (Fig. 3). It can either present in isolation or as part of a genetic disorder, most of which are included among iPPSD (95).

Brachydactyly can be challenging to identify in early childhood, and tends to become more evident during early puberty. Brachydactyly can be overlooked when all bones are short as in acrodysostosis since early childhood. 

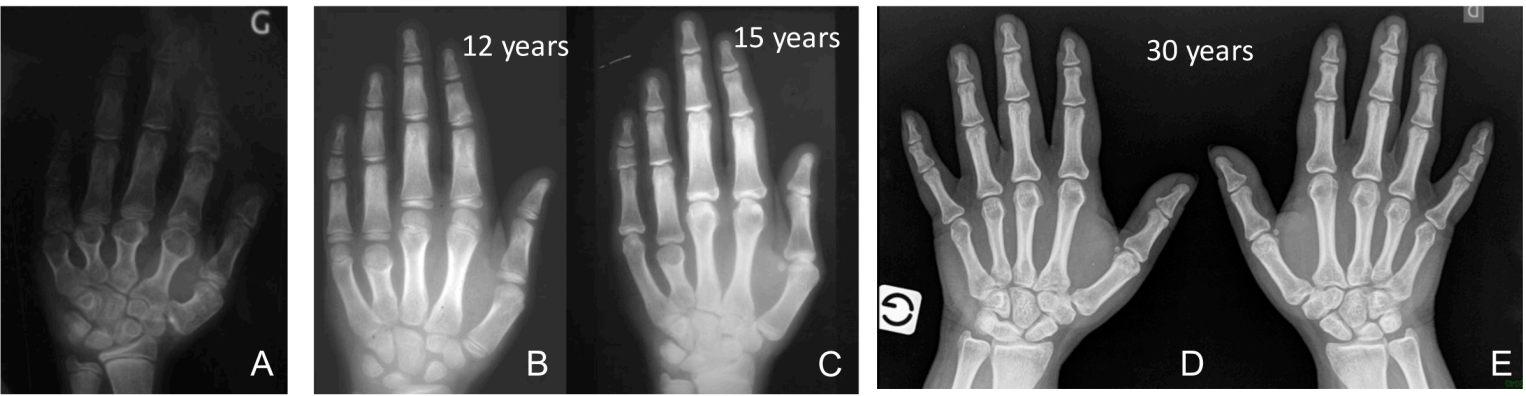

\begin{tabular}{|l|l|l|}
\hline PHP1A & PHP1A & PPI \\
\hline GNAS (p.W154X) & GNAS (p.Asp190MetfsX14) & GN \\
\hline iPPSD2 & iPPSD2 & iPP \\
\hline
\end{tabular}

PPHP
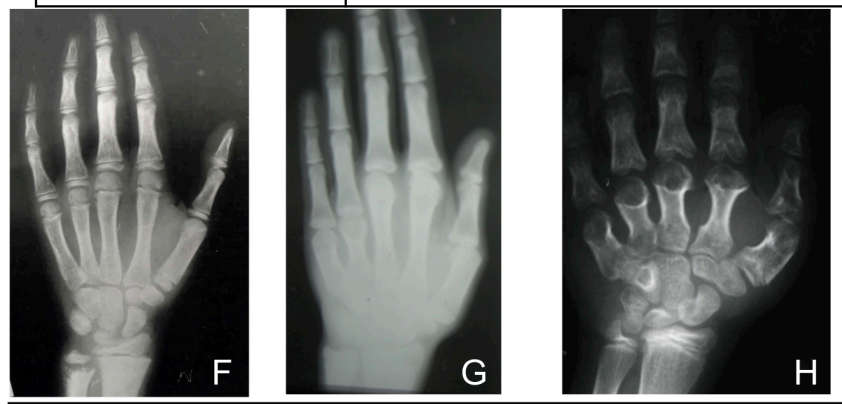

GNAS (p.Asp190MetfsX14) iPPSD2

\begin{tabular}{|l|l|l|l|l|}
\hline PHP1B & PHP1B & ACRDYS & ACRDYS & ACRDYS \\
\hline del STX16 & Broad LOI & PRKAR1A (p. R368X) & PRKAR1A (p.T239A) & PDE4D \\
\hline iPPSD3 & iPPSD3 & iPPSD4 & iPPSD4 & iPPSD5 \\
\hline
\end{tabular}

Figure 3

Patterns of brachydactyly type E associated with iPPSD. A, B, C, D and E, brachydactylies associated with coding mutations in the Gsa subunit of the $G$ protein (iPPSD2). F and G, bone phenotype associated with the loss of imprinting at the GNAS locus (iPPSD3). $\mathrm{H}, \mathrm{I}$ and J, brachydactylies associated with the molecular defect in PRKAR1A (iPPSD4) and PDE4D (iPPSD5). Note the phenotypic overlap between $A, H$, J and $B, C, G, I$ respectively.

While PTH resistance and ectopic ossifications are considered major criteria for iPPSD, brachydactyly is less specific and should, therefore, be combined with at least one major or two minor criteria to trigger the diagnosis of iPPSD.

\section{Minor criteria}

\section{Thyroid-stimulating hormone (TSH) resistance}

In iPPSD, TSH resistance is often mild and characterised by elevated TSH levels associated with free thyroxine $\left(\mathrm{T}_{4}\right)$ levels in a normal or low-normal reference range. This occurs in the absence of goitre and markers of autoimmune disease $(26,27)$. TSH resistance can sometimes be the first detected sign of iPPSD, especially in countries where screening for congenital hypothyroidism is routinely performed (96).

\section{Other hormone resistances}

Very few other hormone resistances have been demonstrated so far. Resistance to growth hormonereleasing hormone $(\mathrm{GHRH})$, leading to growth hormone deficiency, is the most frequent additional resistance found in PHP1A, affecting as many as 60\% of patients $(97,98,99)$. Calcitonin resistance has been described without clinical features in patients affected with PHP1A (27). Elevated follicular-stimulating hormone (FSH) and luteinizing hormone ( $\mathrm{LH})$ levels were reported both by us and Namnoum et al. (78, 100). Glucagon and adrenaline resistances were demonstrated in patients 
with features of PHP and low Gsa bioactivity through in vivo testing $(6,101)$.

\section{Motor and cognitive retardation or impairment}

Psychomotor and cognitive alterations have been described in about 40 to $70 \%$ of the patients with a maternal coding mutation of GNAS $(25,34)$, as well as in some patients affected with acrodysostosis (83, 85, 86). Psychiatric manifestations have also been reported in these patients (102). Patients with paternal mutations of GNAS or epigenetic modifications of the GNAS DMRs seem unaffected $(25,63)$.

\section{Intrauterine and postnatal growth retardation}

Intrauterine growth retardation (IUGR) has been frequently observed in both maternal and paternal inherited inactivating GNAS coding mutations. However, IUGR is more pronounced in patients harbouring mutations on the paternal GNAS allele, mainly when affecting GNAS exon 2-13 mutations, compared with patients with GNAS exon 1/intron 1 mutations (103). IUGR has also been described in acrodysostosis with mutations in PRKAR1A or PDE4D, and in patients with mutations in PDE3A $(16,82,90,92)$. A LOI at the maternal GNAS A/B: TSS-DMR has been associated with increased intrauterine growth (104).

Postnatal growth retardation is a frequent sign in PHP1A and acrodysostosis. Growth hormone deficiency and premature closure of the epiphysis result in short stature $(16,82,97,105)$. Growth retardation has also been observed in PHP1B, although only in exceptional cases $(71,74)$, and in patients with Eiken dysplasia (10).

\section{Obesity/overweight}

Obesity or overweight may be the most nonspecific minor sign; however, it occurs very frequently in disorders with an impaired PTH/PTHrP signalling pathway and may help to differentiate between the different subtypes. Growth hormone deficiency, impaired lipolytic response of adrenaline (101) or decreased resting energy expenditure (106) contribute to the development of obesity in patients with mutations on the maternal allele of GNAS $(23,107)$. Obesity is also a frequent feature in patients affected with acrodysostosis $(16,90,108)$.

\section{Flat nasal bridge and/or maxillar hypoplasia and/or round face}

Elements of facial dysmorphism have been associated with acrodysostosis (flat nasal bridge and/or maxillar hypoplasia) or with PHP1A (round face) $(4,86)$.

\section{Diagnosis of iPPSD}

We propose that a minimum of one of the major criteria is mandatory for the clinical diagnosis of iPPSD. PTH resistance or ectopic ossifications may lead to the diagnosis of iPPSD with or without the presence of minor criteria. However, brachydactyly type E (BDE) should be associated with at least one major or two minor criteria to suggest iPPSD, as it is a common feature of several other diseases and syndromes (Table 3 ).

The known molecular causes of PTH/PTHrP signalling disorders are:

- inactivating mutations of PTH1R;

- inactivating heterozygous mutations in the coding sequence of GNAS-Gsa;

- methylation changes of the DMRs of GNAS caused by

- deletions or duplications at ICRs (STX16; NESP; GNAS-AS1);

- paternal UPD of chromosome 20q;

- unknown mechanism(s);

- heterozygous mutations of PRKAR1A;

- heterozygous mutations of PDE4D;

- heterozygous mutations of PDE3A.

In contrast to the former diagnostic classification based solely on the phenotype, once iPPSD has been identified (using criteria described Table 3), we propose to further subtype iPPSD based on the underlying molecular (epi) genetic defect. Therefore, the term iPPSD will refer to the pathophysiology of the PTH/PTHrP signalling abnormalities, while the number will refer to the underlying molecular mechanism (responsible for the pathology). We have numbered iPPSD subtypes starting with PTH1R mutations.

\section{The novel classification of iPPSD}

The European PHP network proposes the following classification (Fig. 4):

- iPPSD: clinical/biochemical diagnosis based on the major/minor criteria as defined above, in the absence of genetic investigation;

- iPPSD1: loss-of-function mutation in PTH1R;

- iPPSD2: loss-of-function mutation in Gsa; 


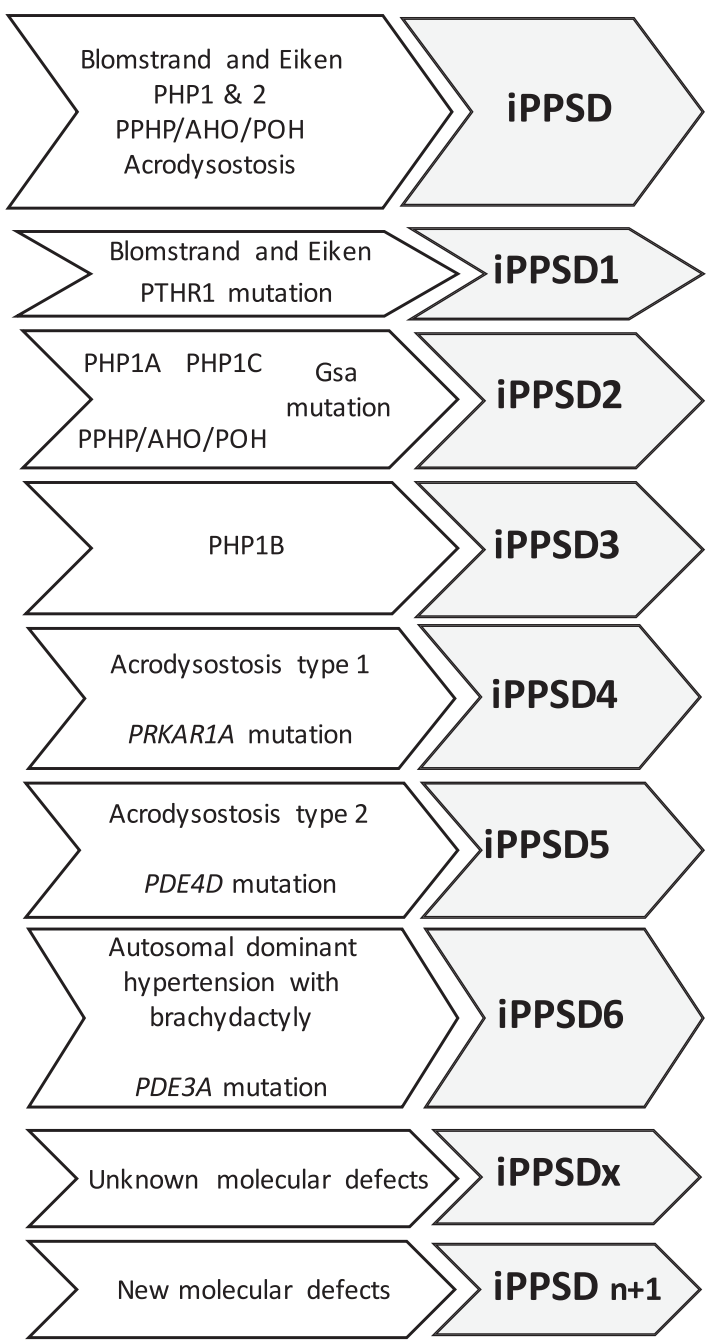

Figure 4

Schematic representation of the new classification proposed by the European PHP network. According to the suggested new classification Blomstrand and Eiken chondrodysplasia, PHP type 1 and 2, PPHP, AHO, POH and acrodysostosis clinically/biochemically diagnosed without genetic investigation are named iPPSD; Blomstrand and Eiken chondrodysplasia due to PTHR1-inactivating mutations are named iPPSD1; PHP1A, PHP1C, PPHP and POH clinically diagnosed and characterised by Gsa-inactivating mutations are termed iPPSD2; PHP1B clinically diagnosed and due to methylation changes at the GNAS DMRs is classified as IPPSD3; in the presence of acrodysostosis type 1 or PRKAR1A mutations, the disease is classified as iPPSD4. Acrodysostosis type 2 or PDE4D mutations are termed iPPSD5; PDE3A mutations are categorised as iPPSD6; patients lacking genetic or epigenetic defects at the known genes fall under the category of iPPSDx; any newly discovered genetic/molecular defects will be labelled as iPPSDn+1.
- iPPSD3: methylation change(s) at one or more GNAS DMRs, associated with or without a genetic (deletion) or cytogenetic (UPD) defect;

- iPPSD4: PRKAR1A mutation;

- iPPSD5: PDE4D mutation;

- iPPSD6: PDE3A mutation;

- iPPSDx: lack of genetic/epigenetic defect identified following molecular investigation of known genes described above;

- iPPSDn+1: the identification of a novel gene/molecular defect will lead to a disease named iPPSD7, then 8 and so on.

iPPSD3 encompasses all disorders associated with changes in the methylation patterns of the DMRs of GNAS, including UPD(20)pat and deletion within STX16, NESP etc. Of most significance is the common mechanism shared by these patients, i.e. the LOM at the GNAS $A / B$ :TSS-DMR. Grouping them under iPPSD3 highlights this common mechanism. Secondly, we anticipated the difficulties in integrating the multiplicity of the epigenetic mechanisms within the classification system as this adds no further diagnostic value. However, the further specification of the epigenetic defect can remain part of a private exchange between the molecular laboratory, the patient and his/ her physician.

We recommend the use of Arabic numerals to avoid the confusion with letters (II with the number 11 for example).

The advantages of this new nomenclature are: (i) it stratifies the disorders into clusters caused by the same mechanism; (ii) it is flexible and open to accommodate new defects to be discovered in the future and (iii) it simplifies the concept of the overlapping disorders under a single umbrella.

This classification, however, bears some limitations. We deliberately did not include the parental origin of the genetic/epigenetic defect, although some iPPSD are imprinting disorders - namely iPPSD2 and iPPSD3 and their phenotypic expression depends on their parental inheritance. The main reason behind this is the association of PTH resistance and $\mathrm{POH}$ with both maternal and paternal inactivating GNAS mutations. Therefore, the mechanism of the two allelic GNAS mutations can be considered alike. However, in daily practice, the parental origin of the GNAS defect should be considered, particularly for genetic counselling. In fact, $\mathrm{AHO}$ and multiple hormone resistance including PTH resistance are largely associated with maternal GNAS coding defects, whereas isolated $\mathrm{AHO}$ and/or $\mathrm{POH}$ are more often associated with paternal GNAS coding defects. 
Another limitation of this classification is the inability to subclassify individuals with a pure clinical suspicion of iPPSD and lack of complete (epi)genetic testing. While such patients cannot be classified as iPPSDx or with a specific number, we recommend that they are classified as iPPSD.

The inclusion of the disorders involving the two main ligands of the PTH1R, i.e. hypoparathyroidism (109) and brachydactyly type $\mathrm{E}$ with short stature (mutations in PTHLH the gene encoding PTHrP $(110,111))$ to the classification may be argued. However, we decided to exclude them due to several other issues such as (i) their different biochemical pattern including low levels of PTH responsible for hypoparathyroidism; (ii) the dramatic difference in the therapy of hypoparathyroidism and defects in PTH1R signalling respectively and (iii) the difference in research goals in the two disease groups.

\section{Perspectives}

We believe that the use of the new nomenclature will facilitate a more straightforward approach to the diagnosis of iPPSD, increase awareness of the red-flag signs of PTH resistance, ectopic ossifications and brachydactyly type E. It would allow for the classification of patients into local catalogues used by the different healthcare organisations in a more homogenous way, and enable future observational and research studies in the field.

We strongly believe that too many denominations for similar diseases and patients with phenocopies (PHP, PPHP, POH, ACRDYS, TRPS, BDE, AHO) have diluted and dispersed research advance, adding undue complexity to the causative mechanism and proved challenging for the experts in building a global research network in the field.

Regular use of the classification in daily practice or for scientific purposes will allow appropriate amendments in the best interest of the patients.

While producing this novel nomenclature and classification, we have identified the need to (i) disseminate this alternative classification to be positively enriched by the clinical and scientific community; (ii) validate the major/minor criteria in a series of patients affected by different iPPSDs and (iii) develop international guidelines for the diagnosis and treatment of the iPPSDs in the near future.

\section{Declaration of interest}

All the authors declare that there is no conflict of interest that could be perceived as prejudicing the impartiality of the research reported.

\section{Funding}

This work and/or members of the network Euro-Pseudohypoparathyroidism network (EuroPHP) was supported by grants obtained from the European Society for Paediatric Endocrinology (ESPE) Research Unit, the University of Luebeck (H02-2011), the Italian Ministry of Health (GR-2009-1608394), Ricerca Corrente Funds (to Fondazione IRCCS Ca' Granda Ospedale Maggiore Policlinico), the Instituto de Salud Carlos III and European fund for Regional Development, FEDER, (PI13/00467 to GPdN), the Basque Department of Health (GV2014111017 to GPdN), the University of Basque Country (Ref: 48198) (to A P), the I3SNS Programme of the Spanish Ministry of Health (CP03/0064; SIVI 1395/09 to GPdN), the APHP Bicêtre Paris-Sud Reference Center for Rare Disorders of the Calcium and Phosphate Metabolism (to A L, C S, V G, P H and A U) as well as the Plateforme d'Expertise Maladies Rares Paris-Sud. All members of the EuroPHP network are members of the EUCID.net (COST action BM1208 on imprinting disorders; www.imprintingdisorders.eu), which was supported by SANDOZ FRANCE for training actions.

Author contribution statement

S Thiele, G Mantovani, G Perez de Nanclares and A Linglart contributed equally to the manuscript; all the other members of the EuroPHP are listed in alphabetical order.

\section{References}

1 Mantovani G. Clinical review: pseudohypoparathyroidism: diagnosis and treatment. Journal of Clinical Endocrinology and Metabolism 2011 96 3020-3030. (doi:10.1210/jc.2011-1048)

2 Weinstein LS, Yu S, Warner DR \& Liu J. Endocrine manifestations of stimulatory $\mathrm{G}$ protein alpha-subunit mutations and the role of genomic imprinting. Endocrine Reviews 200122 675-705. (doi:10.1210/edrv.22.5.0439)

3 Turan S \& Bastepe M. The GNAS complex locus and human diseases associated with loss-of-function mutations or epimutations within this imprinted gene. Hormone Research in Paediatrics $2013 \mathbf{8 0}$ 229-241. (doi:10.1159/000355384)

4 Albright F, Burnett CH, Smith PH \& Parson W. Pseudohypoparathyroidism - an example of "Seabright-Bantam syndrome". Endocrinology 194230 922-932.

5 Chase LR, Melson GL \& Aurbach GD. Pseudohypoparathyroidism: defective excretion of $3^{\prime}, 5^{\prime}$-AMP in response to parathyroid hormone. Journal of Clinical Investigation 196948 1832-1844. (doi:10.1172/JCI106149)

6 Levine MA, Downs RW Jr, Moses AM, Breslau NA, Marx SJ, Lasker RD, Rizzoli RE, Aurbach GD \& Spiegel AM. Resistance to multiple hormones in patients with pseudohypoparathyroidism. Association with deficient activity of guanine nucleotide regulatory protein. American Journal of Medicine 198374 545-556. (doi:10.1016/0002-9343(83)91008-2)

7 Cheloha RW, Gellman SH, Vilardaga J-P \& Gardella TJ. PTH receptor-1 signalling-mechanistic insights and therapeutic prospects. Nature Reviews Endocrinology 201511 712-724. (doi:10.1038/nrendo.2015.139)

8 Blomstrand S, Claësson I \& Säve-Söderbergh J. A case of lethal congenital dwarfism with accelerated skeletal maturation. Pediatric Radiology 198515 141-143. (doi:10.1007/BF02388725)

9 Zhang P, Jobert AS, Couvineau A \& Silve C. A homozygous inactivating mutation in the parathyroid hormone/parathyroid hormone-related peptide receptor causing Blomstrand chondrodysplasia. Journal of Clinical Endocrinology and Metabolism 199883 3365-3368. (doi:10.1210/jcem.83.9.5243)

10 Duchatelet S, Ostergaard E, Cortes D, Lemainque A \& Julier C. Recessive mutations in PTHR1 cause contrasting skeletal dysplasias in Eiken and Blomstrand syndromes. Human Molecular Genetics 2005 14 1-5. (doi:10.1093/hmg/ddi118) 
11 Hoogendam J, Farih-Sips H, Wÿnaendts LC, Löwik CWGM, Wit JM $\&$ Karperien M. Novel mutations in the parathyroid hormone (PTH)/PTH-related peptide receptor type 1 causing Blomstrand osteochondrodysplasia types I and II. Journal of Clinical Endocrinology and Metabolism 200792 1088-1095. (doi:10.1210/jc.2006-0300)

12 Stone M, Hosking D, Garcia-Himmelstine C, White D, Rosenblum D $\&$ Worth $\mathrm{H}$. The renal response to exogenous parathyroid hormone in treated pseudohypoparathyroidism. Bone 199314 727-735. (doi:10.1016/8756-3282(93)90204-N)

13 Drezner M, Neelon FA \& Lebovitz HE. Pseudohypoparathyroidism type II: a possible defect in the reception of the cyclic AMP signal. New England Journal of Medicine 1973289 1056-1060. (doi:10.1056/ NEJM197311152892003)

14 Rao DS, Parfitt AM, Kleerekoper M, Pumo BS \& Frame B. Dissociation between the effects of endogenous parathyroid hormone on adenosine 3',5'-monophosphate generation and phosphate reabsorption in hypocalcemia due to vitamin D depletion: an acquired disorder resembling pseudohypoparathyroidism type II. Journal of Clinical Endocrinology and Metabolism 198561 285-290. (doi:10.1210/jcem-61-2-285)

15 Rodriguez HJ, Villarreal H Jr, Klahr S \& Slatopolsky E. Pseudohypoparathyroidism type II: restoration of normal renal responsiveness to parathyroid hormone by calcium administration. Journal of Clinical Endocrinology and Metabolism 1974 39 693-701. (doi:10.1210/jcem-39-4-693)

16 Linglart A, Menguy C, Couvineau A, Auzan C, Gunes Y, Cancel M, Motte E, Pinto G, Chanson P, Bougnères $P$ et al. Recurrent PRKAR1A mutation in acrodysostosis with hormone resistance. New England Journal of Medicine 2011364 2218-2226. (doi:10.1056/ NEJMoa1012717)

17 Levine MA, Downs RW Jr, Singer M, Marx SJ, Aurbach GD \& Spiegel AM. Deficient activity of guanine nucleotide regulatory protein in erythrocytes from patients with pseudohypoparathyroidism. Biochemical and Biophysical Research Communications 1980941319 1324. (doi:10.1016/0006-291X(80)90563-X)

18 Farfel Z, Brickman AS, Kaslow HR, Brothers VM \& Bourne HR. Defect of receptor-cyclase coupling protein in psudohypoparathyroidism. New England Journal of Medicine 1980303 237-242. (doi:10.1056/ NEJM198007313030501)

19 Radeke HH, Auf'mkolk B, Jüppner H, Krohn HP, Keck E \& Hesch RD. Multiple pre- and postreceptor defects in pseudohypoparathyroidism (a multicenter study with twenty four patients). Journal of Clinical Endocrinology and Metabolism 198662 393-402. (doi:10.1210/jcem62-2-393)

20 Silve C, Santora A, Breslau N, Moses A \& Spiegel A. Selective resistance to parathyroid hormone in cultured skin fibroblasts from patients with pseudohypoparathyroidism type Ib. Journal of Clinical Endocrinology and Metabolism 198662 640-644. (doi:10.1210/jcem-62-4-640)

21 Albright F, Forbes AP \& Henneman PH. Pseudopseudohypoparathyroidism. Transactions of the Association of American Physicians 195265 337-350.

22 Eyre WG \& Reed WB. Albright's hereditary osteodystrophy with cutaneous bone formation. Archives of Dermatology $1971 \mathbf{1 0 4}$ 634-642. (doi:10.1001/archderm.1971.04000240058008)

23 Long DN, McGuire S, Levine MA, Weinstein LS \& Germain-Lee EL. Body mass index differences in pseudohypoparathyroidism type $1 \mathrm{a}$ versus pseudopseudohypoparathyroidism may implicate paternal imprinting of Galpha(s) in the development of human obesity. Journal of Clinical Endocrinology and Metabolism 200792 1073-1079. (doi:10.1210/jc.2006-1497)

24 Farfel Z \& Friedman E. Mental deficiency in pseudohypoparathyroidism type I is associated with Ns-protein deficiency. Annals of Internal Medicine 1986105 197-199. (doi:10.7326/0003-4819-105-2-197)

25 Mouallem M, Shaharabany M, Weintrob N, Shalitin S, Nagelberg N, Shapira H, Zadik Z \& Farfel Z. Cognitive impairment is prevalent in pseudohypoparathyroidism type Ia, but not in pseudopseudohypoparathyroidism: possible cerebral imprinting of Gsalpha. Clinical Endocrinology 200868 233-239. (doi:10.1111/ j.1365-2265.2007.03025.x)

26 Balavoine AS, Ladsous M, Velayoudom FL, Vlaeminck V, Cardot-Bauters C, d'Herbomez M \& Wemeau JL. Hypothyroidism in patients with pseudohypoparathyroidism type Ia: clinical evidence of resistance to TSH and TRH. European Journal of Endocrinology 2008159 431-437. (doi:10.1530/EJE-08-0111)

27 Vlaeminck-Guillem V, D’Herbomez M, Pigny P, Fayard A, Bauters C, Decoulx M \& Wémeau JL. Pseudohypoparathyroidism Ia and hypercalcitoninemia. Journal of Clinical Endocrinology and Metabolism 200186 3091-3096. (doi:10.1210/jcem.86.7.7690)

28 Linglart A, Maupetit-Méhouas S \& Silve C. GNAS-related loss-offunction disorders and the role of imprinting. Hormone Research in Paediatrics 201379 119-129. (doi:10.1159/000348516)

29 Brix B, Werner R, Staedt P, Struve D, Hiort O \& Thiele S. Different pattern of epigenetic changes of the GNAS gene locus in patients with pseudohypoparathyroidism type Ic confirm the heterogeneity of underlying pathomechanisms in this subgroup of pseudohypoparathyroidism and the demand for a new classification of GNAS-related disorders. Journal of Clinical Endocrinology and Metabolism 201499 E1564-E1570. (doi:10.1210/jc.2013-4477)

30 Thiele S, de Sanctis L, Werner R, Grotzinger J, Aydin C, Juppner H, Bastepe M \& Hiort O. Functional characterization of GNAS mutations found in patients with pseudohypoparathyroidism type Ic defines a new subgroup of pseudohypoparathyroidism affecting selectively Gsalpha-receptor interaction. Human Mutation 201132 653-660. (doi:10.1002/humu.21489)

31 Hirai T, Chagin AS, Kobayashi T, Mackem S \& Kronenberg HM. Parathyroid hormone/parathyroid hormone-related protein receptor signaling is required for maintenance of the growth plate in postnatal life. PNAS 2011108 191-196. (doi:10.1073/ pnas.1005011108)

32 Patten JL, Johns DR, Valle D, Eil C, Gruppuso PA, Steele G, Smallwood PM \& Levine MA. Mutation in the gene encoding the stimulatory $\mathrm{G}$ protein of adenylate cyclase in Albright's hereditary osteodystrophy. New England Journal of Medicine 1990322 1412-1419. (doi:10.1056/NEJM199005173222002)

33 Elli FM, deSanctis L, Ceoloni B, Barbieri AM, Bordogna P, Beck-Peccoz P, Spada A \& Mantovani G. Pseudohypoparathyroidism type Ia and pseudo-pseudohypoparathyroidism: the growing spectrum of GNAS inactivating mutations. Human Mutation 201334 411-416. (doi:10.1002/humu.22265)

34 Thiele S, Werner R, Grötzinger J, Brix B, Staedt P, Struve D, Reiz B, Farida J \& Hiort O. A positive genotype-phenotype correlation in a large cohort of patients with pseudohypoparathyroidism type Ia and pseudo-pseudohypoparathyroidism and 33 newly identified mutations in the GNAS gene. Molecular Genetics \& Genomic Medicine 20153 111-120. (doi:10.1002/mgg3.2015.3.issue-2)

35 Lemos MC \& Thakker RV. GNAS mutations in pseudohypoparathyroidism type 1a and related disorders. Human Mutation 201536 11-19. (doi:10.1002/humu.2015.36.issue-1)

36 Weinstein LS, Gejman PV, Friedman E, Kadowaki T, Collins RM, Gershon ES \& Spiegel AM. Mutations of the Gs alpha-subunit gene in Albright hereditary osteodystrophy detected by denaturing gradient gel electrophoresis. PNAS 199087 8287-8290.

37 Mantovani G, Bondioni S, Linglart A, Maghnie M, Cisternino M, Corbetta S, Lania AG, Beck-Peccoz P \& Spada A. Genetic analysis and evaluation of resistance to thyrotropin and growth hormonereleasing hormone in pseudohypoparathyroidism type Ib. Journal of Clinical Endocrinology and Metabolism 200792 3738-3742. (doi:1210/ jc.2007-0869)

38 Ham H-J, Baek K-H, Lee J-Y, Kim SY, Mo EY, Kim ES, Han JH \& Moon SD. Analysis of aberrantly spliced transcripts of a novel de novo GNAS mutant in a male with albright hereditary 
osteodystrophy and PHP1A. Hormone and Metabolic Research 201547 585-590. (doi:10.1055/s-0034-1395678)

39 Lin MH, Numbenjapon N, Germain-Lee EL \& Pitukcheewanont P. Progressive osseous heteroplasia, as an isolated entity or overlapping with Albright hereditary osteodystrophy. Journal of Pediatric Endocrinology and Metabolism 201528 911-918. (doi:10.1515/jpem-2014-0435)

40 Geneviève D, Sanlaville D, Faivre L, Kottler M-L, Jambou M, Gosset P, Boustani-Samara D, Pinto G, Ozilou C, Abeguilé G et al. Paternal deletion of the GNAS imprinted locus (including Gnasxl) in two girls presenting with severe pre- and post-natal growth retardation and intractable feeding difficulties. European Journal of Human Genetics 200513 1033-1039. (doi:10.1038/sj.ejhg.5201448)

41 Fernandez-Rebollo E, García-Cuartero B, Garin I, Largo C, Martínez F, Garcia-Lacalle C, Castaño L, Bastepe M \& Pérez de Nanclares G. Intragenic GNAS deletion involving exon A/B in pseudohypoparathyroidism type $1 \mathrm{~A}$ resulting in an apparent loss of exon A/B methylation: potential for misdiagnosis of pseudohypoparathyroidism type 1B. Journal of Clinical Endocrinology and Metabolism 201095 765-771. (doi:10.1210/jc.2009-1581)

42 Fernandez-Rebollo E, Barrio R, Pérez-Nanclares G, Carcavilla A, Garin I, Castaño L \& de Nanclares GP. New mutation type in pseudohypoparathyroidism type Ia. Clinical Endocrinology 200869 705-712. (doi:10.1111/cen.2008.69.issue-5)

43 Mitsui T, Nagasaki K, Takagi M, Narumi S, Ishii T \& Hasegawa T. A family of pseudohypoparathyroidism type Ia with an 850-kb submicroscopic deletion encompassing the whole GNAS locus. American Journal of Medical Genetics Part A 2012 158A 261-264. (doi:10.1002/ajmg.a.34393)

44 Garin I, Elli FM, Linglart A, Silve C, de Sanctis L, Bordogna P, Pereda A, Clarke JT, Kannengiesser C, Coutant R et al. Novel microdeletions affecting the GNAS locus in pseudohypoparathyroidism: characterization of the underlying mechanisms. Journal of Clinical Endocrinology and Metabolism 2015100 E681-E687. (doi:10.1210/jc.2014-3098)

45 Adegbite NS, Xu M, Kaplan FS, Shore EM \& Pignolo RJ. Diagnostic and mutational spectrum of progressive osseous heteroplasia $(\mathrm{POH})$ and other forms of GNAS-based heterotopic ossification. American Journal of Medical Genetics Part A 2008 146A 1788-1796. (doi:10.1002/ajmg.a.32346)

46 Shore EM, Ahn J, Jan de Beur S, Li M, Xu M, Gardner RJM, Zasloff MA, Whyte MP, Levine MA \& Kaplan FS. Paternally inherited inactivating mutations of the GNAS1 gene in progressive osseous heteroplasia. New England Journal of Medicine 2002346 99-106. (doi:10.1056/NEJMoa011262)

47 Hayward B \& Bonthron D. An imprinted antisense transcript at the human GNAS1 locus. Human Molecular Genetics 20009 835-841. (doi:10.1093/hmg/9.5.835)

48 Yu S, Yu D, Lee E, Eckhaus M, Lee R, Corria Z, Accili D, Westphal H \& Weinstein LS. Variable and tissue-specific hormone resistance in heterotrimeric Gs protein alpha-subunit (Gsalpha) knockout mice is due to tissue-specific imprinting of the gsalpha gene. PNAS 199895 8715-8720.

49 Mantovani G, Ballare E, Giammona E, Beck-Peccoz P \& Spada A. The gsalpha gene: predominant maternal origin of transcription in human thyroid gland and gonads. Journal of Clinical Endocrinology and Metabolism 200287 4736-4740. (doi:10.1210/jc.2002-020183)

50 Liu J, Litman D, Rosenberg MJ, Yu S, Biesecker LG \& Weinstein LS. A GNAS1 imprinting defect in pseudohypoparathyroidism type IB. Journal of Clinical Investigation 2000106 1167-1174. (doi:10.1172/JCI10431)

51 Bastepe M, Fröhlich LF, Hendy GN, Indridason OS, Josse RG, Koshiyama H, Körkkö J, Nakamoto JM, Rosenbloom AL, Slyper AH et al. Autosomal dominant pseudohypoparathyroidism type Ib is associated with a heterozygous microdeletion that likely disrupts a putative imprinting control element of GNAS. Journal of Clinical Investigation 2003112 1255-1263. (doi:10.1172/JCI19159)

52 Linglart A, Gensure RC, Olney RC, Jüppner H \& Bastepe M. A novel STX16 deletion in autosomal dominant pseudohypoparathyroidism type $\mathrm{Ib}$ redefines the boundaries of a cis-acting imprinting control element of GNAS. American Journal of Human Genetics 200576 804-814. (doi:10.1086/429932)

53 Bastepe M, Fröhlich LF, Linglart A, Abu-Zahra HS, Tojo K, Ward LM \& Jüppner H. Deletion of the NESP55 differentially methylated region causes loss of maternal GNAS imprints and pseudohypoparathyroidism type Ib. Nature Genetics 200537 25-27. (doi:10.1038/ng1560)

54 Richard N, Abeguilé G, Coudray N, Mittre H, Gruchy N, Andrieux J, Cathebras P \& Kottler ML. A new deletion ablating NESP55 causes loss of maternal imprint of A/B GNAS and autosomal dominant pseudohypoparathyroidism type Ib. Journal of Clinical Endocrinology and Metabolism 201297 E863-E867. (doi:10.1210/jc.2011-2804)

55 Elli FM, de Sanctis L, Peverelli E, Bordogna P, Pivetta B, Miolo G, Beck-Peccoz P, Spada A \& Mantovani G. Autosomal dominant pseudohypoparathyroidism type Ib: a novel inherited deletion ablating STX16 causes loss of imprinting at the A/B DMR. Journal of Clinical Endocrinology and Metabolism 201499 E724-E728. (doi:10.1210/jc.2013-3704)

56 Chillambhi S, Turan S, Hwang D-Y, Chen H-C, Jüppner H \& Bastepe M. Deletion of the noncoding GNAS antisense transcript causes pseudohypoparathyroidism type Ib and biparental defects of GNAS methylation in cis. Journal of Clinical Endocrinology and Metabolism 201095 3993-4002. (doi:10.1210/jc.2009-2205)

57 Rezwan FI, Poole RL, Prescott T, Walker JM, Karen Temple I \& Mackay DJG. Very small deletions within the NESP55 gene in pseudohypoparathyroidism type 1b. European Journal of Human Genetics 201523 494-499. (doi:10.1038/ejhg.2014.133)

58 Takatani R, Molinaro A, Grigelioniene G, Tafaj O, Watanabe T, Reyes M, Sharma A, Singhal V, Raymond FL, Linglart A et al. Analysis of multiple families with single individuals affected by pseudohypoparathyroidism type Ib (PHP1B) reveals only one novel maternally inherited GNAS deletion. Journal of Bone and Mineral Research 201631 796-805. (doi:10.1002/jbmr.2731)

59 Bastepe M, Lane AH \& Jüppner H. Paternal uniparental isodisomy of chromosome 20q-and the resulting changes in GNAS1 methylationas a plausible cause of pseudohypoparathyroidism. American Journal of Human Genetics 200168 1283-1289.

60 Fernández-Rebollo E, Lecumberri B, Garin I, Arroyo J, BernalChico A, Goñi F, Orduña R, Spanish PHP Group, Castaño L \& de Nanclares GP. New mechanisms involved in paternal 20q disomy associated with pseudohypoparathyroidism. European Journal of Endocrinology 2010163 953-962. (doi:10.1530/EJE-10-0435)

61 Dixit A, Chandler KE, Lever M, Poole RL, Bullman H, Mughal MZ, Steggall M \& Suri M. Pseudohypoparathyroidism type $1 \mathrm{~b}$ due to paternal uniparental disomy of chromosome 20q. Journal of Clinical Endocrinology and Metabolism 201398 E103-E108. (doi:10.1210/ jc.2012-2639)

62 Takatani R, Minagawa M, Molinaro A, Reyes M, Kinoshita K, Takatani T, Kazukawa I, Nagatsuma M, Kashimada K, Sato K et al. Similar frequency of paternal uniparental disomy involving chromosome 20q (patUPD20q) in Japanese and Caucasian patients affected by sporadic pseudohypoparathyroidism type Ib (sporPHP1B). Bone 201579 15-20. (doi:10.1016/j. bone.2015.05.011)

63 Maupetit-Méhouas S, Azzi S, Steunou V, Sakakini N, Silve C, Reynes C, Perez de Nanclares G, Keren B, Chantot S, Barlier A et al. Simultaneous hyper- and hypomethylation at imprinted loci in a subset of patients with GNAS epimutations underlies a complex and different mechanism of multilocus methylation defect in pseudohypoparathyroidism type 1b. Human Mutation 201334 1172-1180. (doi:10.1002/humu.22352)

64 Van Dijk FS, Pals G, Van Rijn RR, Nikkels PGJ \& Cobben JM. Classification of Osteogenesis Imperfecta revisited. European Journal of Medical Genetics 201053 1-5. (doi:10.1016/j.ejmg.2009.10.007) 
65 June RR \& Aggarwal R. The use and abuse of diagnostic/classification criteria. Best Practice \& Research. Clinical Rheumatology 201428 921-934. (doi:10.1016/j.berh.2015.04.004)

66 Bonafe L, Cormier-Daire V, Hall C, Lachman R, Mortier G, Mundlos S, Nishimura G, Sangiorgi L, Savarirayan R, Sillence D et al. Nosology and classification of genetic skeletal disorders: 2015 revision. American Journal of Medical Genetics Part A 2015 167A 2869-2892. (doi:10.1002/ajmg.a.37365)

67 Eckardt K-U, Alper SL, Antignac C, Bleyer AJ, Chauveau D, Dahan K, Deltas C, Hosking A, Kmoch S, Rampoldi L et al. Autosomal dominant tubulointerstitial kidney disease: diagnosis, classification, and management-A KDIGO consensus report. Kidney International 201588 676-683. (doi:10.1038/ki.2015.28)

68 Marcucci G, Cianferotti L, Beck-Peccoz P, Capezzone M, Cetani F, Colao A, Davì MV, degli Uberti E, Del Prato S, Elisei R et al. Rare diseases in clinical endocrinology: a taxonomic classification system. Journal of Endocrinological Investigation 201538 193-259. (doi:10.1007/s40618-014-0202-6)

69 Picard C, Al-Herz W, Bousfiha A, Casanova J-L, Chatila T, Conley ME, Cunningham-Rundles C, Etzioni A, Holland SM, Klein C et al. Primary immunodeficiency diseases: an update on the classification from the International Union of Immunological Societies Expert Committee for Primary Immunodeficiency 2015. Journal of Clinical Immunology 201535 696-726. (doi:10.1007/s10875-015-0201-1)

70 Alberti KG \& Zimmet PZ. Definition, diagnosis and classification of diabetes mellitus and its complications. Part 1: diagnosis and classification of diabetes mellitus provisional report of a WHO consultation. Diabetic Medicine: A Journal of the British Diabetic Association 199815 539-553. (doi:10.1002/(SICI)10969136(199807)15:7<539::AID-DIA668>3.0.CO;2-S)

71 de Nanclares GP, Fernandez-Rebollo E, Santin I, Garcia-Cuartero B, Gaztambide S, Menendez E, Morales MJ, Pombo M, Bilbao JR, Barros F et al. Epigenetic defects of GNAS in patients with pseudohypoparathyroidism and mild features of Albright's hereditary osteodystrophy. Journal of Clinical Endocrinology and Metabolism 200792 2370-2373. (doi:10.1210/jc.2006-2287)

72 Unluturk U, Harmanci A, Babaoglu M, Yasar U, Varli K, Bastepe M $\&$ Bayraktar M. Molecular diagnosis and clinical characterization of pseudohypoparathyroidism type-Ib in a patient with mild Albright's hereditary osteodystrophy-like features, epileptic seizures, and defective renal handling of uric acid. American Journal of the Medical Sciences 2008336 84-90. (doi:10.1097/MAJ.0b013e31815b218f)

73 Mariot V, Maupetit-Méhouas S, Sinding C, Kottler M-L \& Linglart A. A maternal epimutation of GNAS leads to Albright osteodystrophy and parathyroid hormone resistance. Journal of Clinical Endocrinology and Metabolism 200893 661-665. (doi:10.1210/jc.2007-0927)

74 Mantovani G, de Sanctis L, Barbieri AM, Elli FM, Bollati V, Vaira V, Labarile P, Bondioni S, Peverelli E, Lania AG et al. Pseudohypoparathyroidism and GNAS epigenetic defects: clinical evaluation of albright hereditary osteodystrophy and molecular analysis in 40 patients. Journal of Clinical Endocrinology and Metabolism 201095 651-658. (doi:10.1210/jc.2009-0176)

75 Izzi B, Decallonne B, Devriendt K, Bouillon R, Vanderschueren D, Levtchenko E, de Zegher F, Van den Bruel A, Lambrechts D, Van Geet $\mathrm{C}$ et al. A new approach to imprinting mutation detection in GNAS by Sequenom EpiTYPER system. International Journal of Clinical Chemistry 2010411 2033-2039. (doi:10.1016/j. cca.2010.08.034)

76 Zazo C, Thiele S, Martín C, Fernandez-Rebollo E, Martinez-Indart L, Werner R, Garin I, Spanish PHP Group, Hiort O \& Perez de Nanclares G. Gs $\alpha$ activity is reduced in erythrocyte membranes of patients with psedohypoparathyroidism due to epigenetic alterations at the GNAS locus. Journal of Bone and Mineral Research 201126 1864-1870. (doi:10.1002/jbmr.369)

77 Turan S, Thiele S, Tafaj O, Brix B, Atay Z, Abali S, Haliloglu B, Bereket A \& Bastepe M. Evidence of hormone resistance in a pseudo- pseudohypoparathyroidism patient with a novel paternal mutation in GNAS. Bone 201571 53-57. (doi:10.1016/j.bone.2014.10.006)

78 Linglart A, Carel JC, Garabédian M, Lé T, Mallet E \& Kottler ML. GNAS1 lesions in pseudohypoparathyroidism Ia and Ic: genotype phenotype relationship and evidence of the maternal transmission of the hormonal resistance. Journal of Clinical Endocrinology and Metabolism 200287 189-197. (doi:10.1210/jcem.87.1.8133)

79 Lebrun M, Richard N, Abeguilé G, David A, Coëslier Dieux A, Journel H, Lacombe D, Pinto G, Odent S, Salles JP et al. Progressive osseous heteroplasia: a model for the imprinting effects of GNAS inactivating mutations in humans. Journal of Clinical Endocrinology and Metabolism 201095 3028-3038. (doi:10.1210/jc.2009-1451)

80 Kaplan FS \& Shore EM. Progressive osseous heteroplasia. Journal of Bone and Mineral Research 200015 2084-2094. (doi:10.1359/ jbmr.2000.15.11.2084)

81 Eddy MC, De Beur SM, Yandow SM, McAlister WH, Shore EM, Kaplan FS, Whyte MP \& Levine MA. Deficiency of the alphasubunit of the stimulatory $\mathrm{G}$ protein and severe extraskeletal ossification. Journal of Bone and Mineral Research 200015 2074-2083. (doi:10.1359/jbmr.2000.15.11.2074)

82 Michot C, Le Goff C, Goldenberg A, Abhyankar A, Klein C, Kinning E, Guerrot AM, Flahaut P, Duncombe A, Baujat G et al. Exome sequencing identifies PDE4D mutations as another cause of acrodysostosis. American Journal of Human Genetics 201290 740-745. (doi:10.1016/j.ajhg.2012.03.003)

83 Lee H, Graham JM Jr, Rimoin DL, Lachman RS, Krejci P, Tompson SW, Nelson SF, Krakow D \& Cohn DH. Exome sequencing identifies PDE4D mutations in acrodysostosis. American Journal of Human Genetics 201290 746-751. (doi:10.1016/j.ajhg.2012.03.004)

84 Maroteaux P \& Malamut G. [Acrodysostosis]. Presse Médicale 196876 2189-2192.

85 Robinow M, Pfeiffer RA, Gorlin RJ, McKusick VA, Renuart AW, Johnson GF \& Summitt RL. Acrodysostosis. A syndrome of peripheral dysostosis, nasal hypoplasia, and mental retardation. American Journal of Diseases of Children 1971121 195-203. (doi:10.1001/archpedi.1971.02100140061002)

86 Reiter S. Acrodysostosis. A case of peripheral dysostosis, nasal hypoplasia, mental retardation and impaired hearing. Pediatric Radiology 19787 53-55. (doi:10.1007/BF00975340)

87 Davies SJ \& Hughes HE. Familial acrodysostosis: can it be distinguished from Albright's hereditary osteodystrophy? Clinical Dysmorphology 19921 207-215.

88 Silve C, Le-Stunff C, Motte E, Gunes Y, Linglart A \& Clauser E. Acrodysostosis syndromes. BoneKEy Reports 20121225. (doi:10.1038/bonekey.2012.225)

89 Ablow RC, Hsia YE \& Brandt IK. Acrodysostosis coinciding with pseudohypoparathyroidism and pseudo-pseudohypoparathyroidism. American Journal of Roentgenology 1977128 95-99. (doi:10.2214/ajr.128.1.95)

90 Linglart A, Fryssira H, Hiort O, Holterhus P-M, Perez de Nanclares G, Argente J, Heinrichs C, Kuechler A, Mantovani G, Leheup B et al. PRKAR1A and PDE4D mutations cause acrodysostosis but two distinct syndromes with or without GPCR-signaling hormone resistance. Journal of Clinical Endocrinology and Metabolism 201297 E2328-E2338. (doi:10.1210/jc.2012-2326)

91 Nagasaki K, Iida T, Sato H, Ogawa Y, Kikuchi T, Saitoh A, Ogata T \& Fukami M. PRKAR1A mutation affecting cAMP-mediated $\mathrm{G}$ proteincoupled receptor signaling in a patient with acrodysostosis and hormone resistance. Journal of Clinical Endocrinology and Metabolism 201297 E1808-E1813. (doi:10.1210/jc.2012-1369)

92 Maass PG, Aydin A, Luft FC, Schächterle C, Weise A, Stricker S, Lindschau C, Vaegler M, Qadri F, Toka HR et al. PDE3A mutations cause autosomal dominant hypertension with brachydactyly. Nature Genetics 201547 647-653. (doi:10.1038/ng.3302)

93 Mantovani G, Elli FM \& Spada A. GNAS epigenetic defects and pseudohypoparathyroidism: time for a new classification? Hormone and Metabolic Research 201244 716-723. (doi:10.1055/s-00000025) 
94 Bastepe M. Genetics and epigenetics of parathyroid hormone resistance. Endocrine Development 201324 11-24. (doi:10.1159/000342494)

95 Pereda A, Garin I, Garcia-Barcina M, Gener B, Beristain E, Ibañez AM $\&$ Perez de Nanclares G. Brachydactyly E: isolated or as a feature of a syndrome. Orphanet Journal of Rare Diseases $2013 \mathbf{8 1 4 1 .}$ (doi:10.1186/1750-1172-8-141)

96 Romanet P, Osei L, Netchine I, Pertuit M, Enjalbert A, Reynaud R $\&$ Barlier A. Case report of GNAS epigenetic defect revealed by a congenital hypothyroidism. Pediatrics 2015135 e1079-e1083. (doi:10.1542/peds.2014-2806)

97 Germain-Lee EL, Groman J, Crane JL, Jan de Beur SM \& Levine MA. Growth hormone deficiency in pseudohypoparathyroidism type 1a: another manifestation of multihormone resistance. Journal of Clinical Endocrinology and Metabolism 200388 4059-4069. (doi:10.1210/jc.2003-030028)

98 Mantovani G, Maghnie M, Weber G, De Menis E, Brunelli V, Cappa M, Loli P, Beck-Peccoz P \& Spada A. Growth hormone-releasing hormone resistance in pseudohypoparathyroidism type ia: new evidence for imprinting of the Gs alpha gene. Journal of Clinical Endocrinology and Metabolism 200388 4070-4074. (doi:10.1210/jc.2002-022028)

99 de Sanctis L, Bellone J, Salerno M, Faleschini E, Caruso-Nicoletti M, Cicchetti M, Concolino D, Balsamo A, Buzi F, Ghizzoni L et al. GH secretion in a cohort of children with pseudohypoparathyroidism type Ia. Journal of Endocrinological Investigation 200730 97-103. (doi:10.1007/BF03347406)

100 Namnoum AB, Merriam GR, Moses AM \& Levine MA. Reproductive dysfunction in women with Albright's hereditary osteodystrophy. Journal of Clinical Endocrinology and Metabolism 199883 824-829. (doi:10.1210/jcem.83.3.4652)

101 Carel JC, Le Stunff C, Condamine L, Mallet E, Chaussain JL, Adnot $\mathrm{P}$, Garabédian $\mathrm{M} \&$ Bougnères $\mathrm{P}$. Resistance to the lipolytic action of epinephrine: a new feature of protein Gs deficiency. Journal of Clinical Endocrinology and Metabolism 199984 4127-4131. (doi:10.1210/jcem.84.11.6145)

102 Kadilli I, Colicchio S, Guglielmo R, Vollono C, Della Marca G \& Janiri L. Clinical insights by the presence of bipolar disorder in pseudohypoparathyroidism type 1A. General Hospital Psychiatry 2015 37 497.e3-497.e5. (doi:10.1016/j.genhosppsych.2015.06.008)

103 Richard N, Molin A, Coudray N, Rault-Guillaume P, Jüppner H \& Kottler M-L. Paternal GNAS mutations lead to severe intrauterine growth retardation (IUGR) and provide evidence for a role of XLos in fetal development. Journal of Clinical Endocrinology and Metabolism 201398 E1549-E1556. (doi:10.1210/jc.2013-1667)

104 Bréhin A-C, Colson C, Maupetit-Méhouas S, Grybek V, Richard N, Linglart A, Kottler ML \& Jüppner H. Loss of methylation at GNAS exon A/B is associated with increased intrauterine growth. Journal of Clinical Endocrinology and Metabolism 2015100 E623-E631. (doi:10.1210/jc.2014-4047)

105 Germain-Lee EL. Short stature, obesity, and growth hormone deficiency in pseudohypoparathyroidism type 1a. Pediatric Endocrinology Reviews 20063 (Supplement 2) 318-327.

106 Shoemaker AH, Lomenick JP, Saville BR, Wang W, Buchowski MS $\&$ Cone RD. Energy expenditure in obese children with pseudohypoparathyroidism type 1a. International Journal of Obesity 201337 1147-1153. (doi:10.1038/ijo.2012.200)

107 Roizen JD, Danzig J, Groleau V, McCormack S, Casella A, Harrington J, Sochett E, Tershakovec A, Zemel BS, Stallings VA et al. Resting energy expenditure is decreased in pseudohypoparathyroidism type 1A. Journal of Clinical Endocrinology and Metabolism 2015101 880-888. (doi:10.1210/jc.2015-3895)
108 Lynch DC, Dyment DA, Huang L, Nikkel SM, Lacombe D, Campeau PM, Lee B, Bacino CA, Michaud JL, Bernier FP et al. Identification of novel mutations confirms PDE4D as a major gene causing acrodysostosis. Human Mutation 201334 97-102. (doi:10.1002/humu.22222)

109 Bilezikian JP, Khan A, Potts JT, Brandi ML, Clarke BL, Shoback D, Jüppner H, D'Amour P, Fox J, Rejnmark L et al. Hypoparathyroidism in the adult: epidemiology, diagnosis, pathophysiology, target-organ involvement, treatment, and challenges for future research. Journal of Bone and Mineral Research 201126 2317-2337. (doi:10.1002/jbmr.483)

110 Klopocki E, Hennig BP, Dathe K, Koll R, de Ravel T, Baten E, Blom E, Gillerot Y, Weigel JF, Krüger G et al. Deletion and point mutations of PTHLH cause brachydactyly type E. American Journal of Human Genetics 201086 434-439. (doi:10.1016/j.ajhg.2010.01.023)

111 Thomas-Teinturier C, Pereda A, Garin I, Diez-Lopez I, Linglart A, Silve C \& de Nanclares GP. Report of two novel mutations in PTHLH associated with brachydactyly type E and literature review. American Journal of Medical Genetics Part A 2016170 734-742. (doi:10.1002/ ajmg.a.37490)

112 Schwindinger WF, Miric A, Zimmerman D \& Levine MA. A novel Gs alpha mutant in a patient with Albright hereditary osteodystrophy uncouples cell surface receptors from adenylyl cyclase. Journal of Biological Chemistry 1994269 25387-25391.

113 Srivastava T, Krudys J, Mardis NJ, Sebestyen-VanSickle J \& Alon US. Cinacalcet as adjunctive therapy in pseudohypoparathyroidism type 1b. Pediatric Nephrology 201631 795-800. (doi:10.1007/s00467-0153271-7)

114 Bakker B, Sonneveld LJH, Woltering MC, Bikker H \& Kant SG. A girl with Beckwith-Wiedemann syndrome and pseudohypoparathyroidism type 1B due to multiple imprinting defects. Journal of Clinical Endocrinology and Metabolism 2015100 3963-3966. (doi:10.1210/jc.2015-2260)

115 Perez-Nanclares G, Velayos T, Vela A, Muñoz-Torres M \& Castaño L. Pseudohypoparathyroidism type Ib associated with novel duplications in the GNAS locus. PLoS ONE 201510 e0117691. (doi:10.1371/journal.pone.0117691)

116 Mehraein Y, Pfob M, Steinlein O, Aichinger E, Eggert M, Bubendorff V, Mannhart A \& Müller S. 2q37.3 deletion syndrome: two cases with highly distinctive facial phenotype, discordant association with schizophrenic psychosis, and shared deletion breakpoint region on 2q37.3. Cytogenetic and Genome Research 2015 146 33-38. (doi:10.1159/000431389)

117 Muhn F, Klopocki E, Graul-Neumann L, Uhrig S, Colley A, Castori M, Lankes E, Henn W, Gruber-Sedlmayr U, Seifert W et al. Novel mutations of the PRKAR1A gene in patients with acrodysostosis. Clinical Genetics 201384 531-538. (doi:10.1111/cge.2013.84.issue-6)

118 Kaname T, Ki C-S, Niikawa N, Baillie GS, Day JP, Yamamura K-I, Ohta T, Nishimura G, Mastuura N, Kim OH et al. Heterozygous mutations in cyclic AMP phosphodiesterase-4D (PDE4D) and protein kinase A (PKA) provide new insights into the molecular pathology of acrodysostosis. Cellular Signalling 201426 2446-2459. (doi:10.1016/j.cellsig.2014.07.025)

119 Lindstrand A, Grigelioniene G, Nilsson D, Pettersson M, Hofmeister W, Anderlid B-M, Kant SG, Ruivenkamp CA, Gustavsson P, Valta H et al. Different mutations in PDE4D associated with developmental disorders with mirror phenotypes. Journal of Medical Genetics 201451 45-54. (doi:10.1136/jmedgenet-2013-101937)

120 Mitsui T, Kim O-H, Hall CM, Offiah A, Johnson D, Jin D-K, Toh TH, Soneda S, Keino D, Matsubayashi S et al. Acroscyphodysplasia as a phenotypic variation of pseudohypoparathyroidism and acrodysostosis type 2. American Journal of Medical Genetics Part A 2014 164A 2529-2534. (doi:10.1002/ajmg.a.36669)

Received 8 February 2016

Revised version received 5 July 2016

Accepted 7 July 2016 